\title{
LIMITATION PERIODS FOR THE ENFORCEMENT OF FOREIGN JUDGMENTS: LAASCH V. TURENNE
}

\author{
NICHOLAS RAFFERTY*
}

\section{FACTS}

Laasch v. Turenne ${ }^{1}$ raised important questions about the available options for the enforcement of foreign judgments in Alberta and emphasized the need for foreign judgment creditors to act very quickly indeed to secure such enforcement. Nathan Laasch was just 16 years old when, in November 2000, he suffered heart failure which resulted in his serious and permanent disability. He lived in Montana and had attended the office of the defendant, Dr. Turenne, on two occasions complaining of episodes of a rapid heart rate, chest discomfort, and lightheadedess. Dr. Turenne also lived in Montana where she practised medicine. She had apparently concluded that she could not diagnose the cause of Nathan's problems, but nonetheless prescribed and administered a beta-blocker. It transpired that Nathan was suffering from Wolff-Parkinson-White syndrome and that beta-blockers were contraindicated for that disease.

Within days of Nathan's heart failure, Dr. Turenne shut down her medical practice, left Montana, moved back to her native Canada, and settled in Bonnyville, Alberta where she worked as a physician. She had been practising in Montana for more than five years before her return to Canada. Nathan and his mother launched an action in Montana against Dr. Turenne for medical malpractice. They served Dr. Turenne in Bonnyville with Montana's equivalent of a statement of claim, but she failed to respond and did not participate in any way in the Montana proceedings. On 5 June 2006, the plaintiffs secured a default judgment in Montana against Dr. Turenne. The judgment was in the amount of US \$5.25 million, comprised of compensatory damages of US \$3.5 million and punitive damages of US \$1.75 million. The plaintiffs sought to enforce that judgment against Dr. Turenne in Alberta.

\section{EARLIER PROCEEDINGS}

The Reciprocal Enforcement of Judgments Act ${ }^{2}$ provides a convenient and expeditious method of enforcing a foreign judgment in Alberta. The Act establishes a system of registration whereby, upon registration in Alberta, a foreign judgment is of the same force and effect as an Alberta judgment. One of the major limitations of the statute is that it is restricted to judgments from reciprocating jurisdictions. There are very few such jurisdictions, although Montana is among them. ${ }^{3}$ The Montana judgment creditors decided to use the REJA to enforce their judgment, and in April 2008 they filed an application to have their Montana judgment registered as a judgment of the Alberta Court of Queen's Bench. There were no limitations issues because section 2(1) of the REJA provides that an

Professor, Faculty of Law, University of Calgary. 2012 ABCA 32, 56 Alta LR (5th) 53 [Laasch]. RSA 2000, c R-6 [REJA].

The other reciprocating jurisdictions are the common law provinces and territories of Canada (and so not Quebec), the Commonwealth of Australia, and the nearby states of Washington and Idaho: Reciprocating Jurisdictions Regulation, Alta Reg 344/1985, s 1. 
application for registration must be made within six years of the date of the original judgment and less than two years had elapsed.

The Court rejected the plaintiffs' application for registration because the defendant had a clear defence to an order for registration under section 2(6)(b) of the REJA. ${ }^{4}$ That provision reads:

No order for registration shall be made if it is shown by the judgment debtor to the Court that

the judgment debtor, being a person who was neither carrying on business nor ordinarily resident within the jurisdiction of the original court, did not voluntarily appear or otherwise submit during the proceedings to the jurisdiction of that court. ${ }^{5}$

By this provision, the REJA reflects the common law position on the enforcement of foreign judgments as it existed at the time of the Act's enactment. Indeed, the statute was never intended to alter significantly the common law, but only to provide a more expeditious procedure for the enforcement of foreign judgments. ${ }^{6}$ Thus, the courts have interpreted section 2(6)(b) in light of the common law to reach the conclusion that the time at which to determine whether the judgment debtor was ordinarily resident or carrying on business in the foreign jurisdiction is the time at which the action was commenced, as Justice Graesser did in this case. ${ }^{7}$ Nathan and his mother, therefore, failed in their application because Dr. Turenne had not submitted to the Montana action in any fashion and was neither ordinarily resident nor carrying on business in Montana at the relevant time. Justice Graesser ended his judgment by stating that, if the plaintiffs still wished to pursue the defendant in Alberta on their Montana judgment, they would "have to do so other than through the Reciprocal Enforcement of Judgments Act.",

\section{Present Proceedings}

Equally, the REJA was never intended to replace the common law means of enforcing a foreign judgment by launching a suit thereon. Thus, the REJA provides that even the taking of proceedings under the Act "does not deprive a judgment creditor of the right to bring an action on the judgment." A separate suit on a foreign judgment is the classic method of enforcing a foreign judgment. Indeed, where the foreign country is not a reciprocating jurisdiction, it is the only mode available. Although it embodies a more cumbersome procedure, the common law method has one substantial advantage represented by the decisions of the Supreme Court of Canada in Morguard Investments Ltd v. De Savoye ${ }^{10}$ and

See Laasch v Turenne, 2009 ABQB 267, 476 AR 377 [Laasch (ABQB)].

REJA, supra note 2, s 2(6)(b).

Canadian Credit Men's Trust Association Ltd v Ryan (1929), [1930] 1 DLR 280 (Alta SC) at 281-82. Laasch $(A B Q B)$, supra note 4 at para 51, citing Kelowna \& District Credit Union v Perl (1984), 55 AR 100 (CA).

Laasch (ABQB), ibid at para 133.

REJA, supra note 2, s 7.

[1990] 3 SCR 1077 [Morguard]. 
Beals v. Saldanha. ${ }^{11}$ As a result of Morguard and Beals, a foreign default judgment is enforceable in Alberta where there is a "real and substantial connection"12 between the foreign jurisdiction and the action or the parties. There was no doubt that the action between Laasch and Turenne satisfied the Morguard/Beals test. Montana was the obvious place for the suit: Montana was where the plaintiffs resided, where the defendant had resided and carried on her medical practice at the time that the cause of action arose, and where the defendant's negligence occurred. Montana clearly had a real and substantial connection with both the subject matter of the action and the parties.

On 25 July 2008, before their application for registration had been heard, the plaintiffs commenced an action in Alberta to enforce their Montana judgment. Just over two years had elapsed since they had obtained their original judgment. The Alberta Court of Appeal held that the plaintiffs' action was out of time by virtue of the Limitations Act, ${ }^{13}$ which provides that:

Subject to section 11, if a claimant does not seek a remedial order within

(a) 2 years after the date on which the claimant first knew, or in the circumstances ought to have known,

(i) that the injury for which the claimant seeks a remedial order had occurred,

(ii) that the injury was attributable to conduct of the defendant, and

(iii) that the injury, assuming liability on the part of the defendant, warrants bringing a proceeding,

or

(b) 10 years after the claim arose,

whichever period expires first, the defendant, on pleading this Act as a defence, is entitled to immunity from liability in respect of the claim. ${ }^{14}$

The Court was in no doubt that the plaintiffs were seeking a "remedial order" within the Act, defined as "a judgment or an order made by a court in a civil proceeding requiring a defendant ... to pay damages for the violation of a right."15 The basic limitation period was, therefore, the two year period set out in section 3(1)(a). The Court then determined that the "injury" occurred on the day that the Montana court granted judgment. ${ }^{16}$ The Montana court had awarded judgment more than two years before the plaintiffs issued their statement of claim in Alberta. Prima facie, therefore, the plaintiffs were statute-barred. The plaintiffs' principal contention was based on section 3(1)(a)(iii) of the Limitations Act. They argued that they did not know, nor should they have known, that the injury warranted bringing a

2003 SCC 72, [2003] 3 SCR 416 [Beals].

Ibid at paras 18-19.

RSA 2000, c L-12.

Ibid, s 3(1).

Ibid, s 1(i). See Laasch, supra note 1 at para 12.

Laasch, ibid at para 17. 
proceeding until their application for registration under the REJA had been dismissed. ${ }^{17}$ The plaintiffs asserted that "they could not reasonably have been expected to sue on the [Montana] judgment without first having attempted the more convenient and cost-effective procedure under the $[R E J A] . " 18$

The Court rejected the plaintiffs' contention. The pending registration application did not justify their delay in filing a statement of claim. The plaintiffs knew that they would have to pursue the defendant in Alberta. They, therefore, knew that some form of proceedings in Alberta was warranted. This was simply a case where the plaintiffs had chosen an incorrect procedure to enforce their Montana judgment. The Court pointed out that the REJA allowed a judgment creditor to bring an action on a foreign judgment, as well as seeking registration under the Act. ${ }^{19}$ Thus, the plaintiffs "could have filed their statement of claim at the same time they filed their registration application, to protect themselves in the event their application was unsuccessful." 20 The Court, therefore, concluded that there was no reason "to find that the [plaintiffs'] error in choice of procedure amount[ed] to a situation in which they did not know, or ought not to have known, that the Montana judgment warranted bringing a proceeding on the date it was granted."21

\section{LIMITATIONS ISSUE}

The general two year limitation period for the enforcement of a foreign money judgment is remarkably short. During that time, "the plaintiff has to find the defendant's assets, retain local lawyers, and start proceedings." 22 In contrast, the limitation period for the enforcement of a domestic judgment is ten years after the claim arose. ${ }^{23}$ Even the REJA provides for a period of six years from the date of the foreign judgment for an application for registration under that statute. ${ }^{24}$

Traditionally, the courts have treated an action on a foreign money judgment as the equivalent to an action on a contract debt and, thus, the limitation period was that applicable to actions for breach of contract. ${ }^{25}$ There have occasionally been decisions, however, favouring the view that, for limitations purposes, foreign judgments should be treated in the same fashion as domestic judgments. In Girsberger v. Kresz, ${ }^{26}$ for example, Justice Cumming rejected the traditional characterization of an action on a foreign judgment. He held that the new, broader rules for the recognition and enforcement of foreign judgments, which had started with Morguard, demanded a change in the perceived wisdom:

In light of ... the clear evolution of the principles of comity, order and fairness, I fail to understand why the characterization of in personam foreign judgments ... as simple contract debts should continue to be the law. In the 19th century, the reasoning behind the historical characterization of in personam foreign judgments,

Ibid at para 18.

Ibid at para 21 .

Ibid at para 26, citing REJA, supra note 2, s 7.

Laasch, ibid at para 25.

Ibid at para 27.

Stephen GA Pitel \& Nicholas S Rafferty, Conflict of Laws (Toronto: Irwin Law, 2010) at 189.

Limitations Act, supra note 13, s 11.

Supra note 2, s 2(1).

See e.g. Livesley $v$ Horst Corp, [1924] SCR 605 at 609-10.

(2000), 47 OR (3d) 145 (SCJ), aff'd on other grounds (2000), 50 OR (3d) 157 (CA) [Girsberger]. 
as I understand it, was the need for Canadian courts to create a new "starting point” when a foreign judgment was recognized and enforced. The principle of territoriality incited the English courts to create a new "starting point" which inferred a promise to pay the amount of the judgment as though it was a simple contract debt. $^{27}$

He continued by determining that the case law that characterized a foreign money judgment as a simple contract debt was based upon "an outmoded conception which emphasize[d] sovereignty and independence at a substantial cost of unfairness to the party wishing to have its foreign judgment enforced in Canada." ${ }^{28}$ According to Justice Cumming, therefore, a foreign judgment should be treated like a domestic judgment for limitations purposes.

Although Justice Cumming's approach garnered some support, ${ }^{29}$ the Ontario Court of

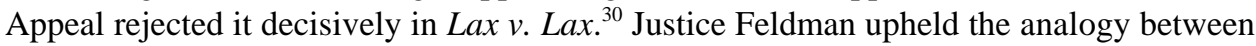
suing on a foreign judgment and suing on a debt. Specifically, she held that no comparison should be drawn between a foreign judgment and a domestic judgment. ${ }^{31} \mathrm{~A}$ foreign judgment creditor had to sue on his or her foreign judgment in order to convert it into a domestic judgment which would then be governed by the limitation period for domestic judgments. ${ }^{32}$

The leading Alberta decision on limitation periods with respect to foreign judgments is Yugraneft Corp v. Rexx Management Corp. ${ }^{33}$ The case dealt with the applicable limitation period for the recognition and enforcement of a foreign arbitral award. Although the Supreme Court of Canada did not wander far beyond that question, the Alberta Court of Appeal had much to say on the applicable limitation period for the enforcement of a foreign judgment. The Court reiterated the position that an action to enforce a foreign judgment was akin to an action on a contract debt "because of the judgment debtor's implied promise to pay the amount of the foreign judgment." 34 Thus, the Court endorsed Lax and rejected the view in Girsberger that a foreign judgment was to be equated with a domestic judgment. ${ }^{35}$ Justice Rowbotham accepted the reasoning of Justice Feldman in Lax that there was no true analogy between domestic judgments and foreign judgments. Whereas domestic judgments could be enforced directly by execution, garnishment, or the appointment of a receiver, foreign judgments could not be enforced until they were first transformed into domestic judgments.

Therefore, actions to enforce foreign judgments fell within the general two year limitation period provided in section 3 of the Limitations Act. The Court of Appeal faced the argument that the two year limit was simply unfair because it might well "take time and effort to learn of the judgment debtor's circumstances and additional time to become familiar with the necessary steps for enforcement outside the jurisdiction.”36 Justice Rowbotham indicated that

Ibid at para 45.

Ibid at para 47.

See e.g. Banque Nationale de Paris (Canada) v Opiola, 2000 ABQB 191, 263 AR 157.

(2004), 70 OR (3d) 520 (CA) [Lax]. See generally Stephen GA Pitel \& Jonathan de Vries, "The Ontario Limitation Period for Actions to Enforce Foreign Judgments” (2004) 29 Advocates’ Q 312.

Lax, ibid at paras 26-27.

Ibid at para 27.

2008 ABCA 274, 433 AR 372, aff'd 2010 SCC 19, [2010] 1 SCR 649 [Yugraneft].

Ibid at para 15.

Ibid at para 23.

Ibid at para 26. 
any such unfairness was alleviated by the fact that the two year period did not start running until "the claimant first knew or ought to have known of its injury, which in this case is the need to enforce an award in a foreign jurisdiction.”37 The Court of Appeal made it crystal clear that the limitation period for the enforcement of a foreign judgment was not the ten year period set out in section 11 of the Limitations Act for the seeking of a remedial order "in respect of a claim based on a judgment or order for the payment of money." ${ }^{8}$ That section contemplated “a domestic judgment or order, not a foreign judgment or order."39

In Laasch there was no longer any dispute that the limitation period applicable to foreign judgments was the general two year period. There was, however, some discussion as to when the period started to run. The Court pointed out that a foreign judgment was traditionally regarded as final upon pronouncement, even though an appeal was pending or the time for appeal had not yet elapsed. ${ }^{40}$ Without deciding the point, the Court intimated that, as a result, for the purposes of the Limitations Act, the injury would have occurred when the foreign judgment was issued, even though at that stage the appeal period had not expired. ${ }^{41}$ Indeed the limitation period would not automatically be extended even if an appeal had actually been launched. Of course, this conclusion emphasizes the short nature of the limitation period for the enforcement of foreign judgments.

In Yugraneft, the Alberta Court of Appeal pointed out that the two year period started to run when the claimant first knew or ought to have known that the injury had occurred. ${ }^{42}$ Justice Rowbotham interpreted "injury" in this context as the need to enforce the judgment in a foreign jurisdiction. ${ }^{43}$ Effectively, the Limitations Act provided for a limitation period of two years after the claimant knew or ought to have known that the judgment needed to be enforced abroad. ${ }^{44}$ Thus, without jeopardizing him or herself, a judgment creditor could take the time to learn of the judgment debtor's circumstances and whereabouts and to become familiar with the remaining steps for enforcing the judgment outside the jurisdiction. ${ }^{45}$

The Court of Appeal in Laasch did not appear to adopt this interpretation. It assumed that the injury occurred upon the pronouncement of a final judgment. That is the natural and obvious interpretation of the statute, but it illustrates that considerable doubt surrounds the effect of the Limitations Act. The Court of Appeal suggested in Laasch that the questions raised in Yugraneft would more easily fall within the issue of whether the injury warranted the bringing of a proceeding within section 3(1)(a)(iii). The Court, however, supplied little guidance as to when an action to enforce a foreign judgment would be regarded as warranted for the purpose of that provision. More uncertainty and confusion, therefore, remain. The legislature could resolve much of the uncertainty if it devised an appropriate limitation period

Ibid at para 24.

Supra note 13.

Yugraneft, supra note 33 at para 32.

Laasch, supra note 1 at para 16. The classic decision on this point is Nouvion v Freeman (1889), 15 App Cas 1 HL (Eng).

Laasch, ibid at para 17.

Supra note 33 at para 24.

Ibid.

Ibid at para 27.

Ibid at para 26. 
that would run from the time when the foreign judgment first became enforceable in the foreign jurisdiction. ${ }^{46}$

\section{PROPOSALS FOR REFORM}

The Alberta Law Reform Institute (ALRI) has recommended the enactment of two pieces of uniform legislation dealing with the enforcement of foreign judgments. ${ }^{47}$ The first is the Uniform Enforcement of Canadian Judgments and Decrees Act. ${ }^{48}$ It is designed to ensure that judgments from other parts of Canada are given full faith and credit in Alberta through a process of registration. It rejects the concept of reciprocity and also rejects any supervisory role for the courts of the enforcing province. Section 5 of the proposed statute adopts the policy that Canadian judgments should be treated no less favourably than local judgments from the perspective of limitations. In accordance with that policy, the ALRI recommended that a ten year period be the limit for the registration of a Canadian judgment under the statute. $^{49}$

More germane to the facts of Laasch itself is the other piece of uniform legislation, the Uniform Enforcement of Foreign Judgments Act. ${ }^{50}$ The UEFJA also establishes a system of registration, this time of non-Canadian judgments, and again registration is not based on reciprocity. The proposed statute incorporates the Morguard test by providing that a foreign court will be regarded as having jurisdiction where "there was a real and substantial connection between the State of origin and the facts on which the proceeding was based."51 Furthermore, the limitation period under that statute is the one provided by the state of origin or ten years from "the day on which the foreign judgment [became] enforceable in that State, whichever is earlier." 52

Unrelated to the limitations issue, it is interesting to note that the UEFJA restricts the enforcement of non-compensatory, including punitive, damages "to the amount of similar or comparable damages that could have been awarded in" 53 the enforcing jurisdiction. No such restriction exists at common law or under the REJA where the rejection of foreign awards of punitive damages is dependent upon the vague principles of public policy. In general, Canadian courts have not been reluctant to enforce foreign awards of punitive damages. ${ }^{54}$ There is thus little doubt that, had the limitation period not expired, the plaintiffs in Laasch would not have been denied recovery of the US \$1.75 million awarded by the Montana court as punitive damages. If the UEFJA were introduced in Alberta, many of the problems of the

See the discussion of the proposals for reform below in Part V.

ALRI, Enforcement of Judgments - Final Report No 94 (Edmonton: ALRI, 2008), online: ALRI $<$ http://www.law.ualberta.ca/alri/docs/fr094.pdf > [ALRI, Enforcement].

Uniform Law Conference of Canada (ULCC), Uniform Enforcement of Canadian Judgments and Decrees Act, online: ULCC <http://www.ulcc.ca/en/us/index.cfm?sec=1\&sub=1e4>, as amended by the Uniform Enforcement of Canadian Judgments and Decrees Act Amendment Act, online: ULCC <http:// www.ulcc.ca/en/us/index.cfm?sec=1\&sub=1e4a\&print $=1>$.

ALRI, Enforcement, supra note 47 at paras 40-41, 86-88.

ULCC, Uniform Enforcement of Foreign Judgments Act, online: ULCC <http://www.ulcc.ca/en/us/ index.cfm?sec $=1 \& \mathrm{sub}=1 \mathrm{e}$ \& $\mathrm{\text {print }}=1>[\mathrm{UEFJ}]$.

Ibid, s 8(f).

Ibid, s 5.

Ibid, s 6(1).

See e.g. Beals, supra note 11; Old North State Brewing v Newlands Services, [1999] 4 WWR 573 (BCCA). 
current limitations regime would be resolved. The courts would, however, be compelled to address the enforceability of non-compensatory damages under the new statutory standard.

\section{CONCLUSION}

Laasch illustrates the point that a foreign judgment creditor who wishes to enforce his or her judgment in Alberta must act very quickly indeed. The limitation period is only two years, and there is still considerable doubt as to when that period starts to run. There is a marked distinction between the period for enforcing a domestic judgment and the period for enforcing a foreign judgment, which is difficult to justify. One of the clear aims of the uniform legislation on the enforcement of judgments is to equate foreign judgments with domestic judgments from the standpoint of limitations. This aim is especially apparent in the case of judgments from other Canadian jurisdictions. One can only hope that those pieces of legislation will be enacted soon.

In Laasch, the plaintiffs attempted to register their Montana judgment under the REJA and then attempted to sue on their judgment at common law. It is worth noting that a third option potentially available to Nathan and his mother would have been to ignore the Montana judgment in their favour and to have sued Dr. Turenne in Alberta on the original cause of action. Of course, any such action is an entirely new one and all issues of liability and compensation would have had to have been re-litigated. In addition, the plaintiffs would have been required to meet the limitation period attaching to the original cause of action. In that regard the plaintiffs would have faced the limitations problems posed by section 12 of Alberta's Limitations Act which mandates the application of Alberta's limitations law in addition to the applicable limitation period of the law governing the cause of action. It provides:

(1) The limitations law of Alberta applies to any proceeding commenced or sought to be commenced in Alberta in which a claimant seeks a remedial order.

(2) Notwithstanding subsection (1), where a proceeding referred to in subsection (1) would be determined in accordance with the law of another jurisdiction if it were to proceed, and the limitations law of that jurisdiction provides a shorter limitation period than the limitation period provided by the law of Alberta, the shorter limitation period applies. ${ }^{55}$

The constitutionality of applying Alberta's limitation period to deny a claim governed by some foreign law was affirmed by the Supreme Court in Castillo v. Castillo. ${ }^{56}$ 